\title{
MADAME D'AULNOY, Contes des Fées suivis des Contes nouveaux ou Les Fées à la Mode
}

\section{Daniela Dalla Valle}

\section{OpenEdition}

\section{Journals}

\section{Edizione digitale}

URL: http://journals.openedition.org/studifrancesi/33133

DOI: 10.4000/studifrancesi.33133

ISSN: 2421-5856

\section{Editore}

Rosenberg \& Sellier

\section{Edizione cartacea}

Data di pubblicazione: 1 décembre 2005

Paginazione: 636

ISSN: 0039-2944

\section{Notizia bibliografica digitale}

Daniela Dalla Valle, «madame d'Aulnoy, Contes des Fées suivis des Contes nouveaux ou Les Fées à la Mode», Studi Francesi [Online], 147 (XLX | III) | 2005, online dal 01 novembre 2015, consultato il 18 avril 2021. URL: http://journals.openedition.org/studifrancesi/33133; DOI: https://doi.org/10.4000/studifrancesi. 33133

Questo documento è stato generato automaticamente il 18 avril 2021.

\section{(c) (i) (9)}

Studi Francesi è distribuita con Licenza Creative Commons Attribuzione - Non commerciale - Non opere derivate 4.0 Internazionale. 


\title{
MADAME D'AULNOY, Contes des Fées suivis des Contes nouveaux ou Les Fées à la Mode
}

\author{
Daniela Dalla Valle
}

\section{NOTIZIA}

MADAME D’AULNoy, Contes des Fées suivis des Contes nouveaux ou Les Fées à la Mode, éd. crit. NADINE JASMIN, Paris, Honoré Champion, 2004, pp. 1220.

1 Questo volume è il primo di una serie di venti, che costituiranno la Bibliothèque des Génies et des Fées, una collezione che si propone di ristampare tutto il Cabinet des Fées (mai più ripreso integralmente), aggiungendo tutti gli altri contes, soprattutto satirici $\mathrm{e}$ licenziosi, che erano stati lasciati da parte nell'edizione del Cabinet del 1785. È un progetto imponente, soprattutto perché si tratterà di un'edizione critica, ricca di note $\mathrm{e}$ di notizie, che offrirà agli studiosi un campo di ricerca esteso ed utilissimo, mai completamente sfruttato.

2 Questo primo volume comprende, in primo luogo, un avvio a tutto il progetto: una presentazione generale di Nadine Jasmin (che è la direttrice della Bibliothèque), un sommario dei venti volumi, un'introduzione a tutto l'insieme di Raymonde Robert (che spiega ed analizza le varie forme di contes, da quelli francesi a quelli orientali, a quelli parodici e licenziosi). Segue un'introduzione - sempre di Raymonde Robert - al primo settore della Bibliothèque, quello definito L'âge d'or du conte de fées (1690-1709), e la presentazione di Nadine Jasmin a questo primo volume, dedicato appunto a Madame d'Aulnoy.

Incomincia poi l'edizione di tutte le novelle di Madame d'Aulnoy, che parte dall'Ile de la Félicité, inserita nel romanzo Histoire d'Hypolite, comte de Douglas (1690), per procedere sui quattro tomi dei Contes des Fées, sui due tomi dei Contes Nouveaux ou Les Fées à la mode e concludendosi con i due volumi della Suite des Contes Nouveaux: tutti i contes sono 
annotati e alla fine sono corredati da una serie di Résumés (che comprendono la presentazione dei personaggi e, quasi sempre, la Moralité), e da una serie di Notices, che analizzano e commentano ogni singolo conte.

4 Una ricca bibliografia e un indice dei personaggi principali dei contes completano il volume.

5 Chiunque, d'ora in poi, vorrà affrontare lo studio delle fiabe di Madame d'Aulnoy dovrà necessariamente fare ricorso a questa edizione. Non possiamo che attendere la prosecuzione del progetto elaborato da Nadine Jasmin, che aprirà agli studiosi, nella sua integralità, un panorama ricco e sostanzialmente nuovo, all'interno della recente ripresa della critica sul genere, nella letteratura tra la fine del Seicento e il Settecento. 